\title{
Marinobacter hydrocarbonoclasticus NY-4, a novel denitrifying, moderately halophilic marine bacterium
}

\author{
Rongpeng $\mathrm{Li}^{1}$, Xiaoli Zi ${ }^{1}$, Xinfeng Wang ${ }^{2}$, Xia Zhang ${ }^{1}$, Haofeng Gao ${ }^{1}$ and Nan $\mathrm{Hu}^{1 *}$
}

\begin{abstract}
The isolation and characterization of a novel halophilic denitrifying marine bacterium is described. The halophilic bacterium, designated as NY-4, was isolated from soil in Yancheng City, China, and identified as Marinobacter hydrocarbonoclasticus by 165 rRNA gene sequence phylogenetic analysis. This organism can grow in $\mathrm{NaCl}$ concentrations ranging from 20 to $120 \mathrm{~g} / \mathrm{L}$. Optimum growth occurs at $80 \mathrm{~g} / \mathrm{L} \mathrm{NaCl}$ and pH 8.0. The organism can grow on a broad range of carbon sources and demonstrated efficient denitrifying ability (94.2\% of nitrate removal and $80.9 \%$ of total nitrogen removal in $48 \mathrm{~h}$ ). During denitrification by NY-4, no $\mathrm{NO}_{2}{ }^{-}-\mathrm{N}$ was accumulated, $\mathrm{N}_{2}$ was the only gaseous product and no harmful $\mathrm{N}_{2} \mathrm{O}$ was produced. Because of its rapid denitrification ability, broad carbon use range and ability to grow under high salinity and $\mathrm{pH}$ conditions, NY-4 holds promise for the treatment of saline waste waters.
\end{abstract}

Keywords: $16 \mathrm{~S}$ rRNA sequence; Denitrification; Marinobacter hydrocarbonoclasticus NY-4; Moderate halophile; Wastewater

\section{Background}

Excessive nitrate contamination in surface and ground water leads to many health and other problems, so that nitrogen $(\mathrm{N})$ removal from water is of great importance (Paerl et al., 2002; Spalding and Exner, 1993). Denitrification is a bacterial process that can remove nitrogen from wastewater through the heterotrophic conversion of nitrate to $\mathrm{N}_{2}$ (Khardnavis et al., 2007). This biological process is highly efficient at nitrogen removal, and does not produce any secondary pollution or residues (Song et al., 2011).

Denitrification occurs in many species of the bacteria and archaea (Zumft 1992), such as Pseudomonas stutzeri (Su et al., 2001), Paracoccus denitrificans (Robertson and Kuenen, 1983), Alcaligenes faecalis (Joo et al., 2005), Bacillus spp. (Kim et al., 2005), and Microvirgula aerodenitrificans (Patureau et al., 2001). Most denitrifying organisms used for biotechnological applications are mesophilic denitrifying bacteria ( $\mathrm{pH}$ optima near 7.0 and

\footnotetext{
*Correspondence: hunannjut@126.com

${ }^{1}$ College of Biotechnology and Pharmaceutical Engineering, Nanjing University of Technology, Nanjing 211800, People's Republic of China Full list of author information is available at the end of the article
}

with low or no salt tolerance). These strains are not always suitable for nitrate removal at high salt concentrations and high $\mathrm{pH}$ of industrial wastewaters (van der Hoek et al., 1987). Unlike domestic or landscape wastewaters, industrial wastewaters are complex matrices, which may contain many cell growth inhibitors (Hockenbury and Grady, 1977; Grunditz et al., 1998), such as high salt concentrations. As previously reported, when the salt concentration was higher than $6 \mathrm{~g} / \mathrm{L}$, a significant drop in the denitrification efficiency was observed, because many bacteria died when the salt concentration was higher than $6 \mathrm{~g} / \mathrm{L}$ (Vendramel et al., 2011).

Use of bacterial strains that have both efficient denitrifying ability and salt tolerance in industrial wastewater treatment may solve this problem. As reported, denitrification under moderately halophilic conditions $(\mathrm{pH}$ range from 7.0 to 9.0 and a salt concentration under $2 \mathrm{M} \mathrm{Na}^{+}$) has been shown for several members of the Gammaproteobacteria, such as Thioalkalivibrio spp. (Sorokin et al., 2001; Sorokin and Kuenen 2005) and Halomonas spp. (Berendes et al., 1996; Mormille et al., 1999; Peyton et al., 2001; Romano et al., 2005; Boltyyansakaya et al., 2004, Boltyanskaya et al. 2007). Some Halomonas strains were 
also demonstrated to actively denitrify under highly halophilic conditions ( $\mathrm{pH} 9.0$ and a salt concentration of $4 \mathrm{M} \mathrm{Na}^{+}$) (Klup et al., 2007; Shapovalova et al., 2008). It is unfortunate that all these reported halophilic species only grew and actively denitrified under aerobic conditions. Because of the low concentrations of dissolved oxygen in industrial wastewaters, these reported aerobic halophilic species were not suitable for application in treatment of industrial wastewater (Shapovalova et al., 2008).

The objective of this research was to isolate and characterize new halophilic denitrifying bacteria with better potential for saline industrial wastewater treatment. To achieve this objective, sediment samples were collected from Xintan Saltern, Yancheng City, Jiangsu Province, China. A halophilic bacterium NY-4 was isolated and identified as Marinobacter $s p$. by $16 \mathrm{~S}$ rRNA analysis. NY-4 has a high anaerobic denitrifying efficiency $(94.2 \%$ nitrite removal and $80.9 \%$ total nitrogen removal in $48 \mathrm{~h}$ ), moderate salt tolerance (from $20 \mathrm{~g} / \mathrm{L}$ to $120 \mathrm{~g} / \mathrm{L}$ ), $\mathrm{pH}$ tolerance (from 7.0 to 9.0 ) and broad carbon use range, which makes NY-4 a promising inoculant for saline industrial wastewater treatment.

\section{Materials and methods}

\section{Strains, medium and culture condition}

NY-4 was isolated from soil in Xintan Saltern, Yancheng City, Jiangsu Province, China, and maintained in $8 \%$ glycerol HSLB plus medium (High Salinity LB medium, $\mathrm{LB}$ with $80 \mathrm{~g} / \mathrm{L} \mathrm{NaCl}$ ) at $-80^{\circ} \mathrm{C}$. For the isolation of bacterial strains, a soil sample was suspended and vortexed thoroughly in sterile $\mathrm{H}_{2} \mathrm{O}$ and serially diluted 10fold four times using sterile $\mathrm{H}_{2} \mathrm{O}$. One hundred $\mu \mathrm{l}$ of the $10^{-4}$ dilution was spread on an HSLB plus plate and incubated at $30^{\circ} \mathrm{C}$ for $48 \mathrm{~h}$. Single colonies were selected. NY-4 was obtained after strict investigation of its purity.

The following indicates the contents of each medium that was prepared: Denitrification medium $(\mathrm{DM}, \mathrm{g} / \mathrm{L})$ : $\mathrm{NaNO}_{3}, 0.607 ; \mathrm{KH}_{2} \mathrm{PO}_{4}, 5 ; \mathrm{NaCl}, 80$, trace element solution, $1 \mathrm{ml}, \mathrm{pH}, 7.0-8.0$; the amount of carbon source varied by experiments; trace element solution $(\mathrm{g} / \mathrm{L}): \mathrm{Na}_{2} \mathrm{EDTA}$, 63.7; $\mathrm{ZnSO}_{4}, 2.2 ; \mathrm{CaCl}_{2}, 5.5 ; \mathrm{MnCl}_{2} 4 \mathrm{H}_{2} \mathrm{O}, 5.06 ; \mathrm{FeSO}_{4} .7 \mathrm{H}_{2} \mathrm{O}$, 5.0; $\mathrm{Na}_{2} \mathrm{MoO}_{4} 4 \mathrm{H}_{2} \mathrm{O}, 1.1 ; \mathrm{CuSO}_{4} 5 \mathrm{H}_{2} \mathrm{O}, 1.57 ; \mathrm{CoCl}_{2} 6 \mathrm{H}_{2} \mathrm{O}$, 1.61, pH, 7.0-7.5. High Salinity LB plus medium (HSLB, $\mathrm{g} / \mathrm{L}$ ): tryptone, 10 ; yeast extract, $5 ; \mathrm{NaCl}, 80 ; \mathrm{KCl}, 5$; $\mathrm{MgSO}_{4} 7 \mathrm{H}_{2} \mathrm{O}, 2.5 ; \mathrm{pH}, 7.0-7.5$. To prepare HSLB plus medium plates, $2 \%(\mathrm{w} / \mathrm{v})$ agar was added. For strain maintenance, glycerol was added into LB plus liquid medium to a final concentration of $8 \%(\mathrm{v} / \mathrm{v})$.

NY-4 was transferred from an HSLB plus frozen culture maintained at $-80^{\circ} \mathrm{C}$ to a fresh HSLB plus medium plate and incubated at $30^{\circ} \mathrm{C}$ for $24 \mathrm{~h}$. NY-4 from the plate was inoculated into the HSLB plus liquid media and incubated at $30^{\circ} \mathrm{C}$ at $150 \mathrm{rpm}$ for $18 \mathrm{~h}$ (about $\mathrm{OD}_{600}$ at 5.0) as the preculture. The preculture was inoculated into DM medium and cultivated as described for each experiment.

\section{Electron microscopy observation}

Detailed cell shapes and flagella were observed both by scanning electron microscopy and transmission electron microscopy. For scanning electron microscopy analysis, bacteria were fixed with $1 \%$ glutaraldehyde overnight and then dehydrated in ethanol completely. Cells were coated with gold-palladium and observed with a JSM5610LV scanning electron microscope (JEOL Ltd., Tokyo, Japan) (Bertrand et al., 1990). For transmission electron microscopy examinations, cells were negatively stained with phosphotungstic acid according to the method of Jahn (1986) and observed with an H-7650 transmission electron microscope (Hitachi, Tokyo, Japan).

\section{$16 \mathrm{~S}$ rRNA analysis}

The 16S rRNA was amplified by PCR using the universal bacterial primers 27F (5'-AGAGTTTGATCCTGGCTC AG-3') and 1492R (5'-GGYTACCTTGTTACGACTT-3') (Lane 1991) and was sequenced by TAKARA Corp. (Dalian, China). The sequence was submitted to a Blast search to compare with available 16S rRNA gene sequences in GenBank of the NCBI database (Altschul et al., 1990). A neighbor-joining tree was constructed using the MEGA 4.0 program (Kumar 2004).

\section{Denitrifying assay}

A $1.5 \mathrm{~mL}$ of preculture of NY-4 in HSLB plus medium was inoculated in $150 \mathrm{~mL}$ of $\mathrm{DM}$ liquid medium sealed with $15 \mathrm{~mL}$ paraffin wax, contained in $250-\mathrm{mL}$ flasks. The flasks were then incubated at $30^{\circ} \mathrm{C}$ in a constant temperature incubator. The cultures were sampled periodically to determine bacterial growth and the concentration of $\mathrm{NO}_{2}^{-}-\mathrm{N}, \mathrm{NO}_{3}^{-}-\mathrm{N}$ and the total nitrogen (TN) were measured every $12 \mathrm{~h}$ during incubation for $72 \mathrm{~h}$. The same denitrification process was performed to detect gaseous nitrogen products, with the exception that tightly sealed infusion bottles $(150 \mathrm{~mL} \mathrm{DM} / 250-\mathrm{mL}$ flask) were used. $\mathrm{N}_{2}$ or $\mathrm{N}_{2} \mathrm{O}$ product was monitored in DM medium at the end of cultivation $(72 \mathrm{~h})$.

\section{Effect of culture conditions on denitrification performance of NY-4}

The effects of the $\mathrm{NaCl}$ concentration, carbon source, $\mathrm{C} / \mathrm{N}$ ratio, and initial $\mathrm{pH}$ on the denitrification performance of NY-4 were investigated by single factor tests (Tang and Luo, 2008).

In experiments to determine the role of the carbon source, sodium succinate, trisodium citrate, sodium acetate and ethanol were used as the sole carbon source in DM. The other conditions were as follows: initial concentration, $100 \mathrm{mg} / \mathrm{L}$ of $\mathrm{NO}_{3}^{-}-\mathrm{N} ; \mathrm{C} / \mathrm{N}=10 ; 80 \mathrm{~g} / \mathrm{L}$ of $\mathrm{NaCl}$; initial $\mathrm{pH}$ 
of 8.0; and temperature of $30^{\circ} \mathrm{C}$. In the experiments to test the effect of $\mathrm{C} / \mathrm{N}$ ratio, trisodium citrate served as the sole carbon source, and the concentration was varied to yield different $\mathrm{C} / \mathrm{N}$ ratios $(1,5,10,15,20,25$ and 30$)$ at a fixed concentration of $\mathrm{NO}_{3}{ }^{-}-\mathrm{N}(100 \mathrm{mg} / \mathrm{L})$. The other conditions were the same as those used for the carbon source experiments. To observe the effects of salinity and initial $\mathrm{pH}$ on nitrogen removal, the concentration of $\mathrm{NaCl}$ in $\mathrm{DM}$ was varied from 0 to $160 \mathrm{~g} / \mathrm{L}$ (at intervals of $20 \mathrm{~g} / \mathrm{L}$ ), and the initial pH from 6.0 to 10.0 (at intervals of $1.0 \mathrm{pH}$ units). These tests were conducted at a $\mathrm{C} / \mathrm{N}$ ratio that demonstrated optimum growth conditions. Samples were collected for the determination of bacterial growth rate, $\mathrm{NO}_{2}^{-}-\mathrm{N}, \mathrm{NO}_{3}^{-}-\mathrm{N}$ and $\mathrm{TN}$ during incubation for $48 \mathrm{~h}$.

\section{Analysis methods}

Bacterial cells were stained with a Gram staining method (Magee et al., 1975), observed and counted in blood counting chamber, using an optical microscope (LW40B, Cewei Corp. Ltd., China). Growth rate was calculated as change in the number of incerased cells vs culturing time during the exponential phase of growth.

Nitrate $\left(\mathrm{NO}_{3}{ }^{-} \mathrm{N}\right)$, nitrite $\left(\mathrm{NO}_{2}^{-}-\mathrm{N}\right)$, and total nitrogen (TN) were determined according to standard methods (APHA et al., 1998), including diphenylamine spectrophotometry, $N$-(1-naphthyl)-1, 2-diaminoethane dihydrochloride spectrophotometry, and potassium persulfate digestion UV spectrophotometric methods, respectively.

The gaseous nitrogen products $\mathrm{N}_{2} \mathrm{O}$ and $\mathrm{N}_{2}$ from headspace were analyzed by gas chromatography (GC97902, Guji Corp. Ltd., China). The conditions were as follows: Packed GC Column [Porapak Q] (mesh size 60/80, $\Phi 3 \times 3 \mathrm{~m}$, Agilent); sample injection port and detector temperature set at $70^{\circ} \mathrm{C}$ and $100^{\circ} \mathrm{C}$, respectively. Gas flow: carrier $\mathrm{H}_{2} 1.2 \mathrm{~mL} / \mathrm{min}$; the added quantity was $600 \mu \mathrm{L}$.

\section{Amplification of the nitrite reductase gene and nitrous oxide reductase of NY-4}

Fragments of the nirS gene of NY-4 were amplified using the primers $\mathrm{cd} 3 \mathrm{~F}$ and $\mathrm{cd} 4 \mathrm{R}$, developed by Michotey et al. (2000). The primer sequences were cd3F: 5'- GT(A/T/C/ G)AA(T/C)GT(A/T/C/G)AA(A/G)GA(A/G)AC(A/T/C/G) GG-3', cd4R: 5'-AC(A/G)TT(A/G)AA(T/C)TT(A/T/C/G) $\mathrm{CC}(\mathrm{A} / \mathrm{T} / \mathrm{C} / \mathrm{G}) \mathrm{GT}(\mathrm{A} / \mathrm{T} / \mathrm{C} / \mathrm{G}) \mathrm{GG}-3$ '. Fragments of the nirK gene of NY-4 were amplified using primers $\mathrm{FlaCu}$ and $\mathrm{R} 3 \mathrm{Cu}$, developed by Hallin et al. (1999). The primer sequences were F1aCu: 5'-ATCATGGT(C/G)CTGCCGCG3', R3Cu: 5'-GCCTCGATCAG(A/G)TTGTGGTT-3'. Fragments of the nos $\mathrm{Z}$ of NY-4 were amplified using primers nosz47F and nosz1776R, referenced with the reported potential nosZ gene (GenBank, GI: 107515115). The primer sequences were nosz47F: 5'-GAGGTTTCCGAAGGTGGT CTG-3', nosz1776R: 5'-GGTCACGGAAGCGGTCTGC-3'. The PCR conditions used were according to the references described for each primer pair. Aliquots of $10 \mu \mathrm{l}$ of the reactions were analyzed by electrophoresis on $2 \%(\mathrm{w} / \mathrm{v})$ agarose gels. Bands were visualized by UV excitation and sequenced by TAKARA Corp. (Dalian, China). The sequences were compared with available reported gene sequences in GenBank using the BLAST program.

\section{Statistical analysis}

All results were shown as the average of at least three independent experiments; variation was expressed as $\mathrm{SD}$. Student's $t$-test, analysis of variance (ANOVA) and the Duncan's multiple range tests were used to determine whether the nitrite- $\mathrm{N}$ degradation rate differed significantly between treatments $(\mathrm{P}<0.05)$. All statistics were performed using SPSS for Windows version 11.0.

\section{Results}

\section{Identification of NY-4}

NY-4 was heterotrophic and able to grow under both aerobic and anaerobic conditions. The colonies of NY-4 were white, circular in shape, with semitransparent, slabby, wet and smooth surfaces on LB plus plates. The cells were Gram-negative, bacilliform with a size of 0.2 $0.3 \mu \mathrm{m}$ in diameter and $2.0-3.0 \mu \mathrm{m}$ in length (Figure 1A), and were motile with general flagellum (Figure 1B). Almost the entire 16S rRNA gene (1502 nt) was PCRamplified and sequenced, and the sequence was submitted to GenBank under the accession number JN903898. The BLAST results indicated that NY-4 was closely related to members of genus Marinobacter, showing the highest 16S rRNA gene sequence similarity (99\%) to Marinobacter hydrocarbonoclasticus. The phylogenetic analysis also showed that NY-4 was grouped together with M. hydrocarbonoclasticus in the tree with 100\% bootstrap support (Additional file 1: Figure S1).

We assessed the anaerobic denitrification performance of NY-4. When inoculated in denitrification DM medium, NY-4 grew quickly, concurrent with a significant and rapid consumption of $\mathrm{NO}_{3}^{-}-\mathrm{N}$ (about $85 \%$ in $48 \mathrm{~h}$ ), showing a high efficiency in denitrification and nitrogen removal capacity (Figure 2). Surprisingly, no $\mathrm{NO}_{2}^{-}-\mathrm{N}$ accumulated was detected throughout the incubation period, which meant that NY-4 could rapidly use $\mathrm{NO}_{2}^{-}-\mathrm{N}$ as an electron acceptor reduced into gaseous nitrogen products (Shao and $\mathrm{Yu}, 2008$ ).

\section{Factors affecting denitrification of NY-4}

We tested the effects of the $\mathrm{NaCl}$ concentration, carbon source, $\mathrm{C} / \mathrm{N}$ ratio, and initial $\mathrm{pH}$ on the denitrification performance of NY-4 by single factor tests (Tang and Luo, 2008). In most different cultivation conditions, NY4 had grown at a maximum cell density and entered the stationary phase when the cultures were sampled at $48 \mathrm{~h}$, except for no growth in extreme unsuitable conditions. In addition, cells of NY-4 at the similar time is in the same 
A

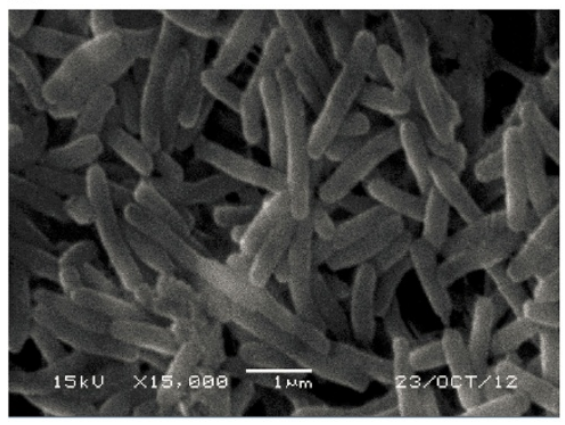

B

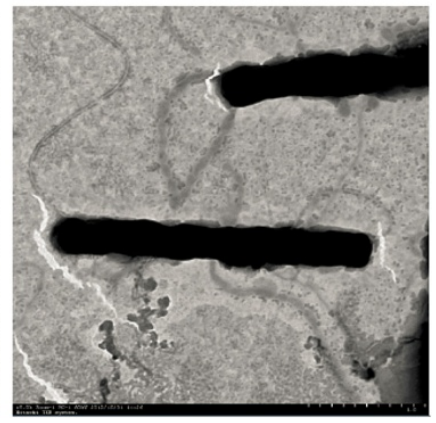

Figure 1 Scanning (A) and transmission (negative staining, B) electron micrographs of $M$. hydrocarbonoclasticus NY-4.

growth phase so that the data of nitrogen removal were significative and comparable with each other.

\section{Salinity concentration}

As the main aim in this study was to isolate and identify strains with both effective denitrifying ability and high tolerance to salinity, we first assessed the denitrifying ability of NY-4 cultured in DM medium with a large range of salt concentrations, from 0 to $160 \mathrm{~g} / \mathrm{L} \mathrm{NaCl}$.

As shown in Figure 3, NY-4 could not grow in DM medium without $\mathrm{NaCl}$. The anaerobic growth rate, $\mathrm{NO}_{3}^{-}-$ $\mathrm{N}$ and TN removal rates of NY-4 increased together until the $\mathrm{NaCl}$ concentration gradually reached $80 \mathrm{~g} / \mathrm{L}$ and decreased with the continuous increase in $\mathrm{NaCl}$ concentration above $80 \mathrm{~g} / \mathrm{L}$. With this concentration, the growth rate of NY-4 was $1.43 \times 10^{6} \mathrm{~mL}^{-1} / \mathrm{h}$ and removal rate of $\mathrm{NO}_{3}{ }^{-} \mathrm{N}$ and $\mathrm{TN}$ were $93.4 \%$ and $79.3 \%$ respectively.

\section{Carbon source}

The carbon source is one of the most important factors affecting denitrifying ability. During the denitrification process, cells use the carbon source as an electron donor and gradually reduce nitrate to $\mathrm{N}_{2}$, thus removing organic matter and nitrate simultaneously. Her and Huang (1995) proposed that the structure and molecular content of the carbon source were significant factors affecting the efficiency of denitrification.

We tested a range of carbon sources to determine the best carbon source affecting the denitrification rate of NY-4 and found it was sodium succinate. When grown on sodium succinate, NY-4 grew the best and exhibited the most efficient denitrifying ability, with a growth rate of $1.38 \times 10^{6} \mathrm{~mL}^{-1} / \mathrm{h}$, while the $\mathrm{NO}_{3}^{-}-\mathrm{N}$ and $\mathrm{TN}$ removal percentages reaching $92.9 \%$ and $83.1 \%$ respectively (Table 1). The results in Table 1 also showed that NY-4 did not grow very well and that denitrification was less efficient with other carbon sources.

Generally speaking, a carbon source with a simple, small molecular structure would be more favorable for denitrification. For NY-4, sodium succinate was the best carbon source, probably because sodium succinate can easily enter the tricarboxylic acid cycle (TCA) and

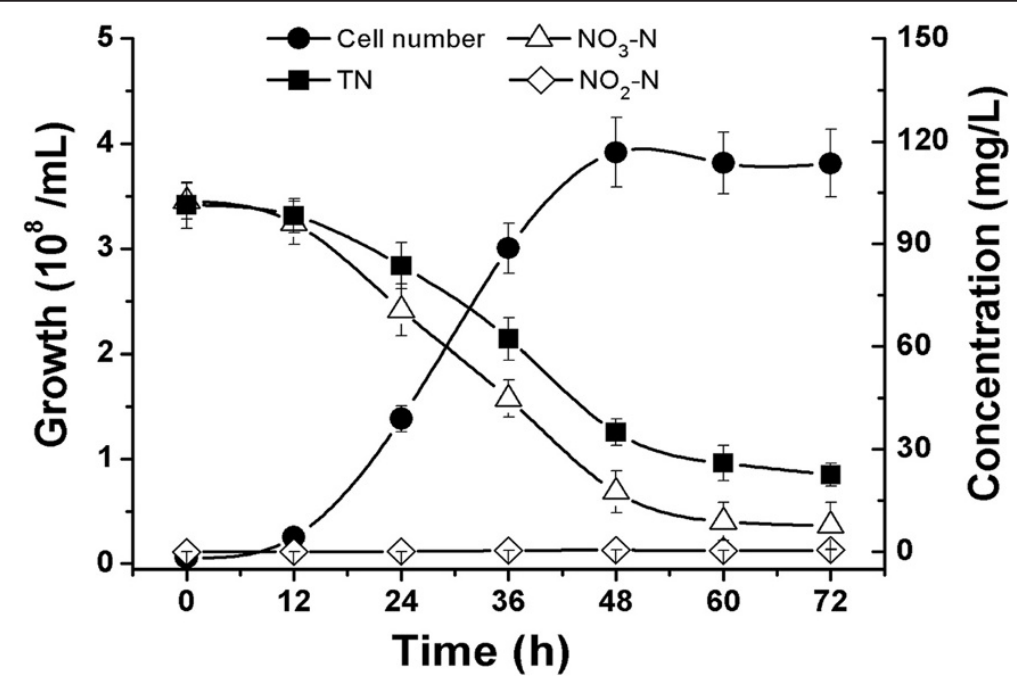

Figure 2 Time course of $M$. hydrocarbonoclasticus NY-4 denitrification in anaerobic. 


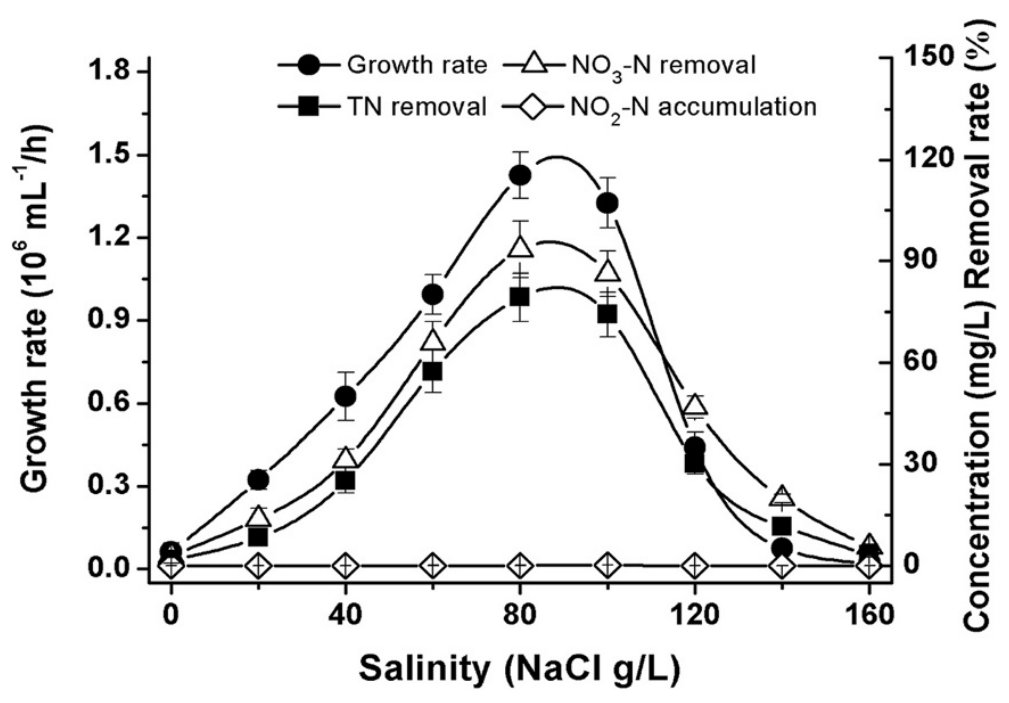

Figure 3 Effects of salinity on the denitrification of $M$. hydrocarbonoclasticus NY-4.

rapidly provide energy and reduction force (Zheng et al., 2012).

\section{$\mathrm{C} / \mathrm{N}$ ratio}

The effect of altering the $\mathrm{C} / \mathrm{N}$ ratio is shown in Figure 4. When the $\mathrm{C} / \mathrm{N}$ ratio was low, such as 1:1, NY-4 did not grow and nearly no $\mathrm{NO}_{3}{ }^{-} \mathrm{N}$ and no $\mathrm{TN}$ were removed. Similar to other denitrifying strains (Lesley et al., 1983), an increase in organic carbon concentration yielded an increase in the denitrification efficiency of anaerobic denitrifier NY-4. When the $\mathrm{C} / \mathrm{N}$ ratio was $10: 1$, the growth rate of NY-4 $\left(1.31 \times 10^{6} \mathrm{~mL}^{-1} / \mathrm{h}\right)$ and removal of both $\mathrm{NO}_{3}^{-}-\mathrm{N}(90.3 \%)$ and $\mathrm{TN}(73.3 \%)$ reached its peak. However, when the $\mathrm{C} / \mathrm{N}$ ratio was higher than 10:1, there was no further improvement in the bacterial growth and nitrogen removal. Taking cost effectiveness into consideration, a $\mathrm{C} / \mathrm{N}$ ratio of 10 was selected as the optimum operating condition for subsequent assays.

pH

The effects of initial $\mathrm{pH}$ are shown in Figure 5. NY-4 could not grow under highly acidic $(\mathrm{pH}<6.0)$ or highly alkaline $(\mathrm{pH}>10.0)$ conditions. Under mesophilic conditions ( $\mathrm{pH} 6.0$ - 8.0), cell growth and $\mathrm{TN}$ removal increased quickly with maximal cell growth rate $(1.39 \times$ $\left.10^{6} \mathrm{~mL}^{-1} / \mathrm{h}\right), \mathrm{NO}_{3}^{-}-\mathrm{N}(92.3 \%)$ and $\mathrm{TN}$ removal (83.4\%) at $\mathrm{pH}$ 8.0. In the $\mathrm{pH}$ range from 8.0 to 10.0 , cell growth rate and nitrogen removal dropped quickly while the denitrifying ability was lost completely in $\mathrm{pH}$ 10.0. For practical wastewater treatment applications, a $\mathrm{pH}$ of 8.0 was chosen as the optimum $\mathrm{pH}$ for the anaerobic denitrification performance for NY-4.

Interestingly, even with all the different factors we changed and assessed, no obvious $\mathrm{NO}_{2}^{-}-\mathrm{N}$ accumulation was detected, which meant that any $\mathrm{NO}_{2}^{-}-\mathrm{N}$ produced was quickly used as an electron donor and converted to $\mathrm{N}_{2} \mathrm{O}$ by NY-4.

\section{Detection of gaseous products of NY-4}

At the end of the incubation of NY-4, lots of bubbles were observed in the cell cultures. Because no $\mathrm{NO}_{2}^{-}-\mathrm{N}$ accumulation was detected, we presumed that any $\mathrm{NO}_{2}^{-}-\mathrm{N}$ formed by denitrification was quickly converted to gaseous products. The gaseous nitrogen products of denitrification are $\mathrm{N}_{2} \mathrm{O}$ or $\mathrm{N}_{2}$ (Jones et al., 2011), which has been demonstrated in some species of bacteria such as Alcaligenes faecalis (Joo et al., 2007). Nitrous oxide and $\mathrm{N}_{2}$ from the

Table 1 Effect of carbon source on the denitrifying performance of NY-4

\begin{tabular}{|c|c|c|c|}
\hline Carbon source & Growth rate $\left(10^{6} \mathrm{~mL}^{-1} / \mathrm{h}\right)$ & $\mathrm{NO}_{3}^{-}-\mathrm{N}$ removal (\% $48 \mathrm{~h}$ ) & TN removal $(\% 48 \mathrm{~h})$ \\
\hline Sodium succinate & $1.29 \pm 0.13$ & $88.8 \pm 2.1$ & $71.0 \pm 3.2$ \\
\hline Trisodium citrate & $1.38 \pm 0.18$ & $92.9 \pm 3.5$ & $83.1 \pm 2.4$ \\
\hline Sodium acetate & $0.68 \pm 0.09$ & $52.1 \pm 3.3$ & $43.9 \pm 4.1$ \\
\hline Ethanol & $0.10 \pm 0.01$ & $8.4 \pm 1.6$ & $6.8 \pm 1.2$ \\
\hline
\end{tabular}




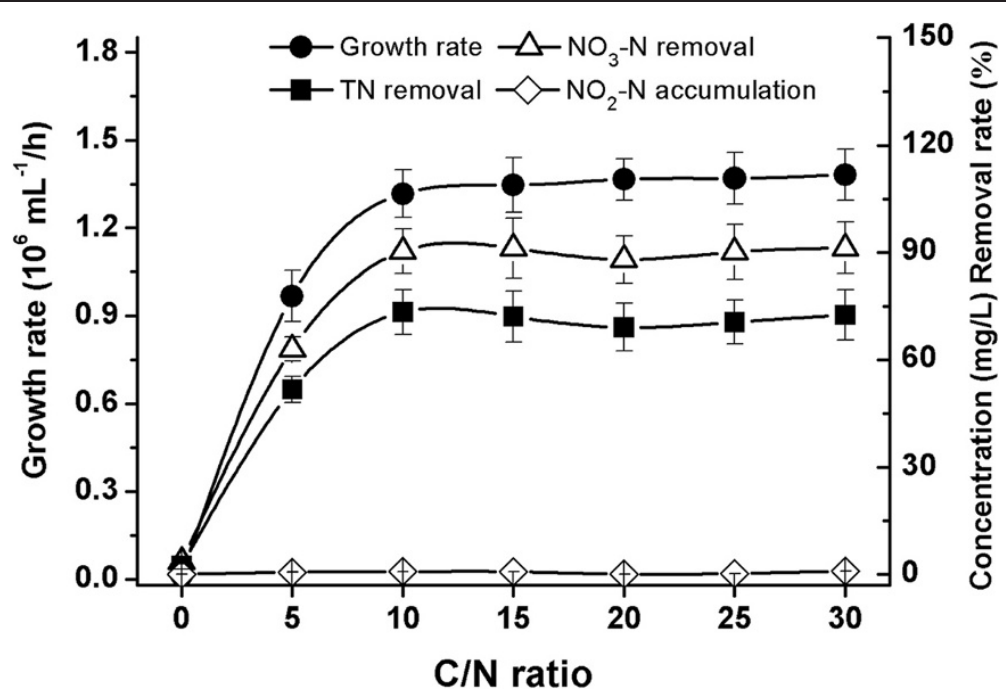

Figure 4 Effects of $\mathrm{C} / \mathrm{N}$ ration on the denitrification of $M$. hydrocarbonoclasticus NY-4.

culture headspace were analyzed by gas chromatography. As shown in Additional file 2: Figure S2, the peak of a standard sample of $\mathrm{N}_{2}$ emerged between $0.664 \mathrm{~min}$ and $1.013 \mathrm{~min}$, while the peak of a standard sample of $\mathrm{N}_{2} \mathrm{O}$ emerged between $2.063 \mathrm{~min}$ and $3.026 \mathrm{~min}$. The peak of gaseous nitrogen production from NY-4 appeared between $0.673 \mathrm{~min}$ to $1.002 \mathrm{~min}$, corresponding to the standard $\mathrm{N}_{2}$ peak. A small peak was detected at 2.095 min, corresponding to $\mathrm{N}_{2} \mathrm{O}$. This result demonstrated that NY-4 could produce both $\mathrm{N}_{2} \mathrm{O}$ and $\mathrm{N}_{2}$ through its denitrification process, but $\mathrm{N}_{2} \mathrm{O}$ was rapidly converted to $\mathrm{N}_{2}$ so that negligible $\mathrm{N}_{2} \mathrm{O}$ was detected (Additional file 2: Figure S2).

\section{Amplification of denitrification nitrite reductase and} nitrous oxide reductase of NY-4

Denitrification is part of the bioenergetic ability of the bacterial cell, where the nitrate and nitrite and the gaseous $\mathrm{NO}$ and $\mathrm{N}_{2} \mathrm{O}$ serve instead of dioxygen $\left(\mathrm{O}_{2}\right)$ as terminal acceptors for electron transport phosphorylation. It is clearly the role of denitrification in the global $\mathrm{N}$ cycle and in cellular bioenergetics that makes a detailed knowledge of this process essential (Zumfit 1997).

Denitrification will be considered as the assemblage of nitrate respiration, nitrite respiration combined with $\mathrm{NO}$ reduction, and $\mathrm{N}_{2} \mathrm{O}$ respiration:

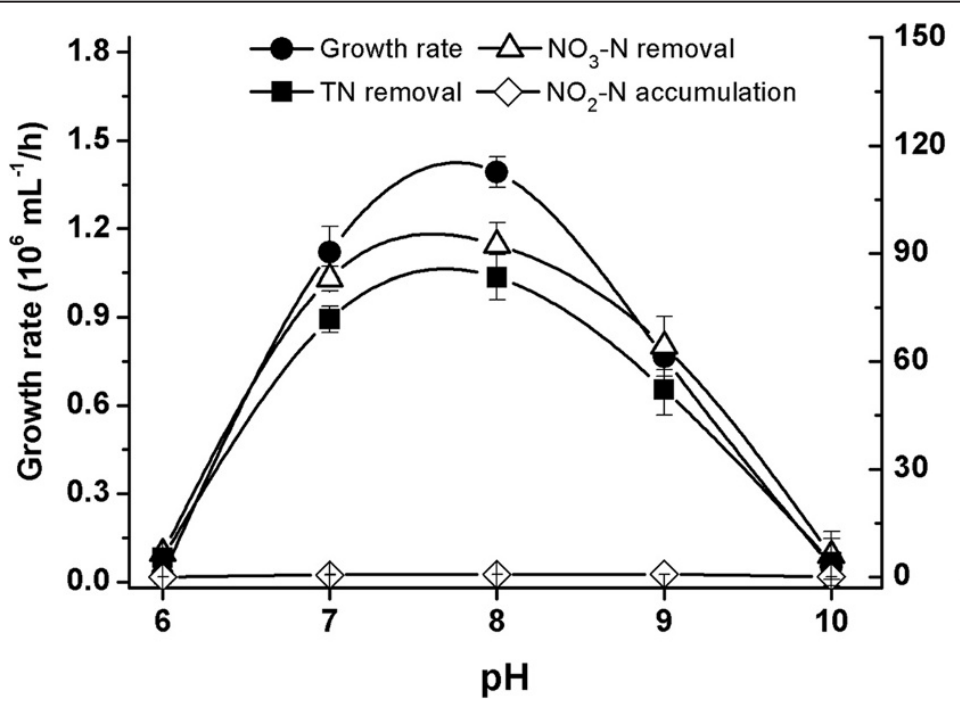




$$
\mathrm{NO}_{3}^{-} \rightarrow \mathrm{NO}_{2}^{-} \rightarrow \mathrm{NO} \rightarrow \mathrm{N}_{2} \mathrm{O} \rightarrow \mathrm{N}_{2}
$$

Nitrite reductase functional genes encode the enzymes that play a key part in the bacterial denitrification process (Song et al., 2011). There have been many reports on the composition and gene sequence of the nitrite reductase (nir) gene, and there are two types of nir gene, nirS (cytochrome cd1-type enzyme) and nirK (copper-based enzyme) (Brake et al., 2000; Ole et al., 2009; Stouthamer 1992). The results of PCR amplification of nitrite reductase genes nirS and nirK from NY-4. are shown in Figure 6. The nirS (1725 nt) amplification was positive, while the nirK amplification was negative. The BLAST result showed this nirS gene shared $97 \%$ homology with reported $M$. hydrocarbonoclasticus potential nirS gene (GenBank, GI: 4657102). These results indicated that the NY-4 had the nirS form of the nitrite reductase gene.

In the denitrifying process, three gases $\left(\mathrm{NO}, \mathrm{N}_{2} \mathrm{O}\right.$ and $\mathrm{N}_{2}$ ) can be produced. Because of the high activity and specificity of NO reductase, NO is hardly accumulated, so the main gaseous products of the denitrifying process are $\mathrm{N}_{2} \mathrm{O}$ and $\mathrm{N}_{2} \cdot \mathrm{N}_{2} \mathrm{O}$ is an important greenhouse gas, with $\sim 320$-fold higher impact than $\mathrm{CO}_{2}$ on greenhouse effect (Lashof and Ahuja, 1990). For this reason it was important to isolate strains that completely denitrify $\mathrm{NO}_{3}^{-}-\mathrm{N}$ to $\mathrm{N}_{2}$. The presence of the nos $Z$ gene, encoding nitrous oxide reductase, indicates whether the strain has the genetic capacity for complete reduction to $\mathrm{N}_{2}$ (Jones et al., 2011).

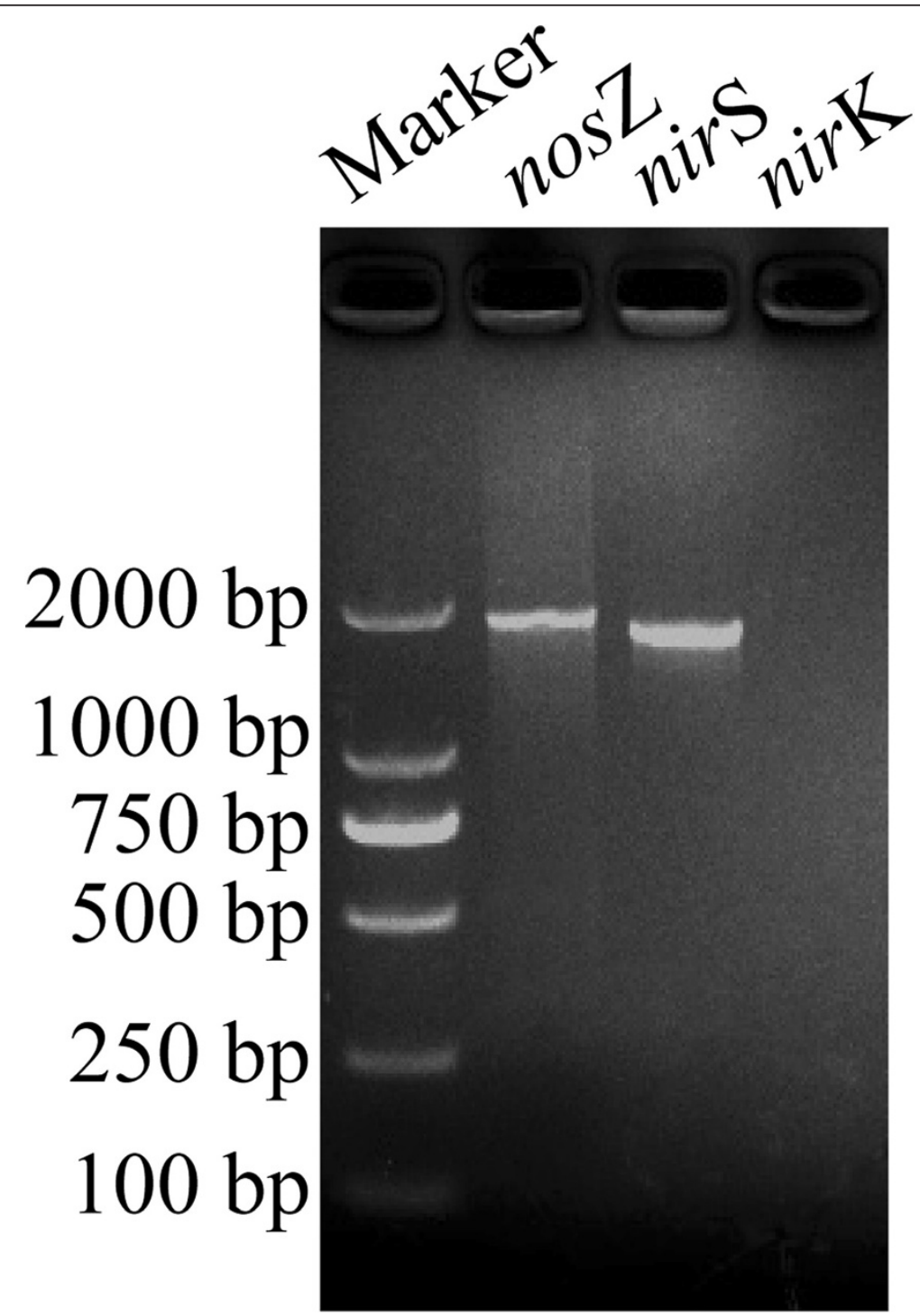

Figure 6 Amplification profiles of nirS, nirK and nosZ gene from M. hydrocarbonoclasticus NY-4. 
We analyzed the gases produced by NY-4 and found that the majority of gas produced was $\mathrm{N}_{2}$ with very little $\mathrm{N}_{2} \mathrm{O}$ accumulation. We were able to amplify the nos $\mathrm{Z}$ gene of NY-4 (1896 nt) (Figure 6). The BLAST result showed this nos Z gene shared 94\% homology with a reported $M$. hydrocarbonoclasticus potential nosZ gene (GenBank, GI: 107515115). We postulate that the nitrous oxide reductase encoded by the nos $Z$ gene of NY-4 had a very high enzymatic activity so that the $\mathrm{N}_{2} \mathrm{O}$ produced was quickly converted to $\mathrm{N}_{2}$.

\section{Discussion}

As we know, industrial wastewaters contain a large amount of nitrates and salt (Glass and Silverstein, 1997; Hirata et al., 2001; Labbe et al., 2003). van der Hoek et al. (1987) and Clifford and Liu (1993) showed that denitrification was possible under $3 \%(\mathrm{w} / \mathrm{w}) \mathrm{NaCl}$ conditions. However, the denitrification rate of saline wastewaters decreased under highly saline conditions (Yang et al., 1995). Therefore, nitrogen removal from saline wastewater has been considered to be difficult (Yoshie et al., 2004). The discovery of denitrifying halophilic bacteria was thought to solve this problem and many such strains have been reported. Most of these strains only grow under aerobic conditions, which limits their use in treatment of low DO industrial wastewaters.

In this study, a novel M. hydrocarbonoclasticus NY-4 was shown to almost completely reduce nitrate under optimum conditions $(80 \mathrm{~g} / \mathrm{L} \mathrm{NaCl}$ and $\mathrm{pH}$ 8.0). Compared with other halophilic species, NY-4 could grow faster (maximum at $\left.1.39 \times 10^{6} \mathrm{~mL}^{-1} / \mathrm{h}\right)$ and to a higher density $\left(3.92 \times 10^{8} \mathrm{~mL}^{-1}\right)$ under anaerobic conditions. M. hydrocarbonoclasticus NY-4 also rapidly converted $\mathrm{NO}_{3}^{-}-\mathrm{N}$ into $\mathrm{N}_{2}$, without $\mathrm{NO}_{2}^{-}-\mathrm{N}$ or $\mathrm{N}_{2} \mathrm{O}$ accumulation. Generally, NY-4 could reduce nitrate within a $\mathrm{NaCl}$ concentration range from 20 to $120 \mathrm{~g} / \mathrm{L}$ and $\mathrm{pH}$ range from 7.0 to 9.0. The strain was also able to use a range of carbon sources for growth and denitrification, such as sodium succinate, trisodium citrate and sodium acetate. Because of its denitrification ability, broad carbon use range and high tolerance to salinity and $\mathrm{pH}, \mathrm{NY}-4$ holds promise for the treatment of saline wastewaters.

We also tested the denitrifying ability of NY-4 under aerobic conditions (data not shown). The best TN removal was only about $40 \%$ under aerobic conditions, which is no better than other reported strains in nitrogen removal. Considering the low dissolved oxygen in industrial wastewaters, NY-4 remains a promising potential inoculant for saline wastewater treatment.

\section{Additional files}

Additional file 1: Figure S1. Phylogenetic tree generated from an alignment of the 16S rRNA.

Additional file 2: Figure S2. GC profiles of the standard gas samples and gaseous production of M. hydrocarbonoclasticus NY-4.

\section{Competing interests}

The authors declare that they have no competing interests.

\section{Authors' contrbutions}

LRP and HN carried out the strains isolation, characteristics, analysis of denitrification ability, and drafted the manuscript. ZXL carried out the $16 \mathrm{~S}$ rRNA gene amplication. WXF carried out researches on effect of culture conditions on cell growth. ZX and GHF participated in the cell cultivations and 165 rRNA sequence alignment. All authors read and approved the final manuscript.

\section{Acknowledgments}

This research was supported by the National Science Foundation of China (No. 51008012) and Open Science Foundation of Jiangsu Key Laboratory for Biomass-based Energy and Enzyme Technology (No. JSBEET1314).

\section{Author details}

${ }^{1}$ College of Biotechnology and Pharmaceutical Engineering, Nanjing University of Technology, Nanjing 211800, People's Republic of China. 2Jiangsu Key Laboratory for Biomass-based Energy and Enzyme Technology, Huaian 223300, People's Republic of China.

Received: 13 April 2013 Accepted: 26 July 2013

Published: 27 July 2013

\section{References}

Altschul SF, Gish W, Miller W, Myers EW, Lipman DJ (1990) Basic local alignment search tool. J Mol Biol 215:403-140

APHA, AWWA, and WPCF (1998) Standards methods for the examination of water and wastewater, 9th edn. APHA, Washington, D.C

Berendes F, Gottschalk G, Heine-Donnernack E, Moore ERB, Tindall BJ (1996) Halomonas desiderata sp. Nov., a new alkaliphilic, halotolerant and denitrifying bacterium isolated from a municipal sewage works. Syst Appl Microbiol 19:158-167

Bertrand JC, Al-Mallah M, Acquaviva M, Mille G (1990) Biodegradation of hydrocarbons by an extremely halophilic archaebacterium. Lett Appl Microbiol 11:260-263

Boltyanskaya YV, Antipov AN, Kolganova TV, Lysenko AM, Kostrikina NA, Zhilina TN (2004) Halomonas campisalis, an obligatorily alkaliphilic, nitrous oxidereducing denitrifier with a molybdenum cofactor-lacking nitrate reductase. Mikrobiologia (Moscow Engl Transl) 73:271-278

Boltyanskaya YV, Kevbrin W, Lysenko AM, Kolganova TV, Tourova TP, Osipov GA, Zhilina TN (2007) Halomonas mongoliensis sp. nov. and Halomonas kenyensis sp. nov., new haloalkaliphilic denitrifiers capable of $\mathrm{N}_{2} \mathrm{O}$ reduction, isolated form soda lakes. Mikrobiologia (Moscow Engl Transl) 76:739-747

Brake G, Zhou J, Wu L, Shou JZ, Allan H (2000) Nitrite reductase genes (nirK and nirS) as functional markers to investigate diversity of denitrifying bacteria in pacific northwest marine sediment communities. Appl Environ Microbool 66:2096-2104

Cliford D, Liu X (1993) Ion exchange for nitrate removal. J Am Water Works Assoc 85:135-143

Glass C, Silverstein J (1997) Denitrification of high-nitrate high-salinity, wastewater. Water Res 33:223-229

Grunditz C, Gumaelius L, Dalhammar G (1998) Comparison of inhibition assays using nitrogen removing bacteria: application to industrial wastewater. Water Res 32:2995-3000

Hallin S, Lindgren P (1999) PCR detection of genes encoding nitrite reductase in denitrifying bacteria. Appl Environ Microbiol 65:1652-1657

Her JJ, Huang JS (1995) Influences of carbon source and C/N ratio on nitrate/ nitrate denitrification and carbon breakthrough. Bioresour Technol 54:45-51

Hirata A, Nakamura Y, Tsuneda S (2001) Nitrogen removal from industrial wastewater discharged from metal recovery processes. Water Sci Technol 44:171-180

Hockenbury MR, Grady CPL Jr (1977) Inhibition of nitrification effects of selected organic compounds. J. Water. Pollut Control Fed 49:768-777

Jahn K (1986) Isolation and characterization of fimbriae form Wscherichia coli. In: Sussman M (ed) The virulence of Escherichia coli. Reviews and methods. The Society for General Microbiology. Academic Press, London, pp 381-388

Jones CM, Weish A, Throback IN, Dorsch P, Bakken LR, Hallin S (2011) Phenotypic and genotypic heterogeneity among closely related soil-borne $\mathrm{N}_{2}$ - and $\mathrm{N}_{2} \mathrm{O}$ - producing Bacillus isolates harboring the nos $Z$ gene. FEMS Micobiol Ecol 76:541-552 
Joo HS, Hirai M, Shoda M (2005) Characteristics of ammonium removal by heterotrophic nitrification-aerobic denitrification by Alcaligenes faecalis no. 4. J Biosci Bioeng 100:184-191

Joo HS, Hirai M, Shoda M (2007) Improvement in ammonium removal efficiency in wastewater treatment by mixed culture of alcaligenes faecalis no. 4 and L1. J Biosci Bioeng 103:66-73

Khardnavis AA, kapley A, Purohit KJ (2007) Simultaneous nitrification and denitrification by diverse Diaphorobacter sp. Appl Microbiol Biotechnol 77:403-409

Kim JK, Paik KJ, Cho KS, Nam S-W, Park TJ, Bajpai R (2005) Aerobic nitrificationdenitrification by heterotrophic Bacilis strains. Bioresour Technol 96:1897-1906

Kulp TR, Han S, Saltikov CW, Lanoil BD, Zargar K, Oremland RS (2007) Effects of imposed salinity gradients on dissimilatory arsenate reduction, sulfate reduction, and other microbial processes in sediments from two California soda lakes. Appl Environ Microbiol 73:5130-5137

Kumar S, Tamura K, Nei M (2004) MEGA3: integrated software for molecular evolutionary genetics analysis and sequence alignment. Brief Bioinform 5:150-163

Labbe N, Juteau P, Parent S, Villemur R (2003) Bacterial diversity in a marine methanol-fed denitrification reactor at the Montreal bidome. Canada Microb Ecol 46:12-21

Lane DJ (1991) 16S/23S rRNA sequencing. In: Stackebrandt E, Goodfellow M (eds) Nucleic acid techniques in bacterial systematics. Wiley, Chichester, pp 115-175

Lashof DA, Ahuja DR (1990) Relative contributions of greenhouse gas emissions to global warming. Nature 344:529-531

Lesley A, Robortson LA, Kuenen JG (1983) Thiosphaera pantotropha gen. nov., sp. Nov. a facultative autotrophic sulphur bacterium. J Gen Microbiol 129:2847-2855

Magee CM, Rodeheaver G, Edgerton MT, Edlich RF (1975) A more reliable Gram staining technique for diagnosis of surgical infections. Am J Surg 130:341-346

Michotey V, Mejean V, Bonin P (2000) Comparison of methods for quantification of cytochrome cd1-denitrification bacteria in environmental marine sample. Appl Environ Microbiol 66:1564-1571

Mormile MR, Romine MF, Garcia MT, Ventosa A, Bailey TJ, Peyton BM (1999) Halomonas campisalis sp. nov., a denitrifying, moderately haloalkaliphilic bacterium. Syst Appl Microbiol 22:551-558

Ole F, Maurizio B, Francesca C, Serena R, Scot W, Israel P (2009) Intramolecular electron transfer in Pseudomonas aeruginosa cd1 nitrite reductase: thermodynamics and kinetics. Biophys J 96:2849-2856

Paerl HW, Dennis RL, Whitall DR (2002) Atmospheric deposition of nitrogen: implications for nutrient over-enrichment of coastal waters. Estuaries 25:677-693

Patureau D, Helloin E, Rustrain E, Bouchez T, Delgenes JP, Moletta R (2001) Combined phosphate and nitrogen removal in a sequencing batch reactor using the aerobic denitrifier., Microvirgula aerodenitrificans. Water Res 35:189-197

Peyton BM, Mormile MR, Petersen JN (2001) Nitrate reduction with Halomonas campsisalis: kinetics of denitrification at $\mathrm{pH} 9$ and $12.5 \% \mathrm{NaCl}$. Water Res 35:4237-4242

Robertson LA, Kuenen JG (1983) Thiosphaera pamtotropha gen. nov., sp. Nov., a facultatively anaerobic, facultatively antotrophic sulphur bacterium. J Gen Microbiol 129:2847-2855

Romano I, Giordano A, Lama L, Nicolaus B, Gambacorta A (2005) Halomonas campaniensis sp. nov., a haloakaliphilic bacterium isolated from a mineral pool of Campania region. Italy Syst Appl Microbiol 28:610-618

Shao Q, Yu XB (2008) Isolation and characterization of a strain denitrifier. J Biotechnol 18:63-65

Shapovalova AA, Khijniak TV, Tourova TP, Muyzer G, Sorokin DY (2008) Heterotrophic denitrification at extremely high salt and $\mathrm{pH}$ by haloalkaliphilic Gammaproteobacteria from hypersaline soda lakes. Extremophiles 12:619-625

Song ZF, An J, Fu GH, Yang XL (2011) Isolation and characterization of an aerobic denitrifying bacillus sp. YX-6 form shrimp culture ponds. Aquaculture 319:188-193

Sorokin DY, Kuenen JG (2005) Alkaliphilic chemolithotrophs from sodas lakes. FEMS Microbiol Ecol 52:287-295

Sorokin DY, Kuenen JG, Jetten M (2001) Denitrification at extremely alkaline conditions in obligately autotrophic alkaliphilic sulfuroxidizing bacterium Thioalkalivibrio denitrificans. Arch Microbiol 175:94-101

Spalding RF, Exner ME (1993) Occurrence of nitrate in groundwater - a review. J Environ Qual 22:392-402
Stouthamer AH (1992) Metabolic pathways in Paracoccus denitrificans and closely related bacterial in relation to the phylogeny of prokaryotes. Anton Leeuw Int JC 61:1-33

Su JJ, Liu BY, Liu CY (2001) Comparison of aerobic denitrification under high oxygen atmosphere by Thiosphaera pantotropha ATCC 35512 and Pseudomonas stutzeri SU2 newly isolated form the activated sludge of a piggery wastewater treatment system. J Appl Microbiol 90:457-462

Tang L, Luo GY (2008) Study on nitrogen removal characteristics of an aerobic denitrifying bacterium Rhodococcus strain T7. Environ Ecol Three Gorges $1: 24-27$

Van der Hoek JP, Latour PJM, Klapwijk A (1987) Denitrification with methanol in the presence of high salt concentrations and at high $\mathrm{pH}$ levels. Appl Microbiol Biotechnol 27:199-205

Vendramel S, Dezotti M, Sant'Anna GL (2011) Nitrification of an industrial wastewater in a moving-bed biofilm reactor: effect of salt concentration. Environmental Technology 32:837-846

Yang PY, Nitisoravut S, Wu JS (1995) Nitrate removal using mixted-culture entrapped microbial cell immobilization process under high salt condition. Water Res 29:1525-1532

Yoshie S, Noda N, Tsuneda S, Hirata A, Inamori Y (2004) Design of 16 S rRNAtargeted oligonucleotide probes and microbial community analysis in the denitrification process of a saline industrial wastewater treatment system. FEMS Lett 235:183-189

Zheng HY, Liu Y, Gao XY, Ai GM, Miao LL, Liu ZP (2012) Characterization of a marine origin aerobic nitrifying-denitrifying bacterium. J Biosci Bioeng $114: 33-37$

Zumft WG (1992) The denitrifying prokaryotes. In: Balows A, Truper HG, Dworkin M, Harder W, Schlerfer K-H (eds) The Prokaryotes, 2nd edn. Springer-Verlag, New York, pp 554-582

Zumft WG (1997) Cell biology and molecular basis of denitrification. Microb Mol Biol Rev 61:533-616

doi:10.1186/2193-1801-2-346

Cite this article as: Li et al:: Marinobacter hydrocarbonoclasticus NY-4, a novel denitrifying, moderately halophilic marine bacterium. SpringerPlus 2013 2:346

\section{Submit your manuscript to a SpringerOpen ${ }^{\circ}$ journal and benefit from:}

- Convenient online submission

- Rigorous peer review

- Immediate publication on acceptance

- Open access: articles freely available online

- High visibility within the field

- Retaining the copyright to your article

Submit your next manuscript at $>$ springeropen.com 